\title{
Relationships between Doses and Application Methods of Phosphorus and Corn Nutrition Status and Grain Yield
}

\section{Evandro Freire Lemos \& Renato de Mello Prado}

To cite this article: Evandro Freire Lemos \& Renato de Mello Prado (2017) Relationships between Doses and Application Methods of Phosphorus and Corn Nutrition Status and Grain Yield, Communications in Soil Science and Plant Analysis, 48:20, 2402-2411, DOI: 10.1080/00103624.2017.1411504

To link to this article: https://doi.org/10.1080/00103624.2017.1411504

\section{曲 Published online: 13 Dec 2017.}

\section{Submit your article to this journal $\widetilde{ }$}

Џ Article views: 56

View Crossmark data ¿ 


\title{
Relationships between Doses and Application Methods of Phosphorus and Corn Nutrition Status and Grain Yield
}

\author{
Evandro Freire Lemos ${ }^{a, b}$ and Renato de Mello Prado ${ }^{c}$ \\ aDoutorando em Agronomia do PPG de Ciência do Solo, Universidade Estadual Paulista "Julio de Mesquita Filho", \\ Jaboticabal, SP, Brasil; 'Universidade do Estado de Minas Gerais, Passos, MG, Brasil; 'Departamento de Solos e \\ Adubos, Faculdade de Ciências Agrárias e Veterinárias, Universidade Estadual Paulista "Julio de Mesquita Filho", \\ Jaboticabal, SP, Brasil
}

\begin{abstract}
The broadcast application of phosphate fertilizers may be more effective than localized application methods for the growth of corn in medium textured oxisol, which have lower phosphorus (P) adsorption capacity. This study aimed to evaluate three phosphate fertilizer application methods at five different doses onto corn grown in oxisol, over two seasons. The experiment was conducted on corn crops in Passos city, Minas Gerais state, Brazil. Stripes with split plots were used to investigate the different application methods where each plot represented double furrow, single furrow, or broadcast application. Within the sub plots, the five doses $(0.0,50,100,200$, and $\left.400 \mathrm{~kg} \mathrm{ha}^{-1}\right)$ of phosphorus pentoxide $\left(\mathrm{P}_{2} \mathrm{O}_{5}\right)$ as granulated monoammonium phosphate (MAP) were applied. Four replications were used. The doses were reapplied in the second cultivation year only for the localized treatments (single and double furrow). The nitrogen in the MAP was held constant among treatments. The corn grain yield in both years was dependent upon both dose and application method, primarily for the single furrow and broadcast methods. In the first year, the broadcast application method of $P$ fertilizer at a estimated dose of $319 \mathrm{~kg} \mathrm{ha}^{-1}$ of $\mathrm{P}_{2} \mathrm{O}_{5}$ provided a greater accumulated yield over two seasons. Broadcast application is therefore a viable method for growing corn with a reduced spacing distribution on medium textured oxisol.
\end{abstract}

\section{ARTICLE HISTORY}

Received 21 September 2016

Accepted 21 July 2017

\section{KEYWORDS}

Broadcast spread; double furrow; leaf diagnosis; phosphate fertilizing; single furrow

\section{Introduction}

The uptake rate of phosphorus (P) by crops is determined by the amount of fertilizer used in relation to the distribution of the plant roots. The adsorption of $\mathrm{P}$ in the soil is reduced by localized application. However, this permits the roots to come into contact with only a small volume of soil. When $\mathrm{P}$ is in contact with a large volume of soil, it becomes less available to the plant because of the large proportion of non-labile P forms (Novais and Smyth 1999). However, if a small number of roots occupy a small volume of soil, even if the soil is rich in phosphorous, the $\mathrm{P}$ needs of the plant may not be met. Thus, for $\mathrm{P}$ absorption to be satisfactory, doses may vary and may primarily depend on the application method.

The compartmentalization of the corn root system observed by Stryker et al. (1974) shows the importance of the well-distributed $\mathrm{P}$ in the soil at the crop implantation time, so that it can be uniformly available to the entire root system of corn plants. This fact shows the possibility of success with broadcast distribution soil-incorporated phosphorus. The most widely used modes of application of phosphate fertilizers are broadcast distributed, soil-incorporated or over the soil surface, in 
the planting furrow, in hills, or in bands (Sousa, lobato, and Rein 2004). Much has to be studied regarding doses and modes of application of $\mathrm{P}$, in a no-tillage system. According to Sá, Briedis, and Ferreira (2013) it is still controversial among researchers a conclusion on this subject. Costa (2008) mentioned to be difficult to identify the mode of application of phosphorus that is the most efficient, since its efficiency is dependent on factors as: soil type, dose to be applied, soil phosphorus content, and row spacing. Also, Sousa and Lobato (2004) affirm that the dose influences the choice of phosphorus application mode, suggesting that doses below $100 \mathrm{~kg} \mathrm{ha}^{-1}$ of $\mathrm{P}_{2} \mathrm{O}_{5}$ must be applied in the sowing furrow, and doses above this value coud be broadcast spread. The fertilization in the sowing furrow has been replaced by the broadcast application without incorporation, aiming at a higher operational efficiency at the sowing period, to make possible to have doble crop in a season (Paludo 2015). Valadão et al. (2016) observed that, in order to speed up sowing operations, Cerrado farmers in the last crop seasons have adopted, for phosphate fertilizers, the broadcast spread method without incorporation.

A study on application methods of $\mathrm{P}$ for corn crops has used plant spacings of $0.90 \mathrm{~m}$, and indicated that localized applications onto soil where $\mathrm{P}$ is highly absorbed would be more feasible than broadcast applications (Prado, Fernandes, and Roque 2001). However, in areas with very low nutrient concentrations, local application may not be satisfactory. Nevertheless, re-applications throughout cultivation might favor a more uniform $\mathrm{P}$ distribution, thus resulting in a high crop yield (Novais et al. 1985). Barreto and Fernandes (2002) investigated the use of broadcast phosphate fertilization on corn grown in yellow argissol soil, which is typical of the coastal tablelands. They observed an increase in leaf $\mathrm{P}$ content and also that the broadcast $\mathrm{P}$ fertilized plants had greater yields and lower $\mathrm{P}$ requirements. However, this soil type is rare in tropical areas.

Reduced spacing between corn plants can increase crop yield (Marchão et al. 2005; Nascimento et al. 2012), by encouraging root distribution patterns that may favor a more efficient use of $P$ when the nutrient is broadcast, especially in medium textured soils with a lower adsorption capacity.

Currently, agribusiness aims to optimize cultivation operations. The use of broadcast applications of fertilizers has increased, with the goal of increasing crop seeder efficiency by reducing machine loading time, due to the exclusion of $\mathrm{P}$ fertilizer.

To optimize the application of phosphate fertilizer under the current practices for corn production, it is important to have a scientific understanding of the processes. We tested the hypothesis that over two seasons, broadcast application of $\mathrm{P}$ in medium texture oxisol would provide appropriate nutrition and high corn crop yield, similar to those obtained with single furrow or double furrow applications.

\section{Material and methods}

The experiment was conducted at the São Bartolomeu farm, located at $20^{\circ} 45^{\prime} 27.34^{\prime \prime} \mathrm{S}$ and $46^{\circ}$ 31'25.92”E, in the municipality of Passos - Minas Gerais, Brazil. The soil was classified as dystrophic oxisol (Embrapa, 2013). The regional climate, according to the Köppen and Geiger (1928) classification, was Cwa, subtropical/tropical with dry winters and hot summers, and an average annual rainfall of $1.800-2.000 \mathrm{~mm}$.

Soil samples were collected in layers of $0-20 \mathrm{~cm}$ and $20-40 \mathrm{~cm}$ for grain size analysis according to the methodology of Camargo et al. (2009) and chemical analysis for fertility in accordance with Raij et al. (2001).

The results of the chemical analysis revealed the following values at $0-20$ and $20-40 \mathrm{~cm}$ depth, respectively, M.O. (Organic Matter) $=23$ and $16 \mathrm{~g} \mathrm{dm}^{-3} ; \mathrm{CaCl}_{2}$ (Calcium Chloride) $\mathrm{pH}=5.0$ and 4.7; P resin $=2$ and $2 \mathrm{mg} \mathrm{dm}^{-3} ; \mathrm{K}($ Potassium $)=1.3$ and $1.6 \mathrm{mmol} \mathrm{dm}^{-3} ; \mathrm{Ca}($ Calcium $)=13$ and $08 \mathrm{mmol}_{\mathrm{c}} \mathrm{dm}^{-3}$; $\mathrm{Mg}($ Magnesium $)=4$ and $2 \mathrm{mmol}_{\mathrm{c}} \mathrm{dm}^{-3} ; \mathrm{Al}$ (Aluminum) $=1$ and $3 \mathrm{mmol}_{\mathrm{c}} \mathrm{dm}^{-3} ; \mathrm{H}+\mathrm{Al}=29$ and $29 \mathrm{mmol}^{-}$ $\mathrm{dm}^{-3} ; \mathrm{SB}$ (sum of bases) $=19$ and $12 \mathrm{mmol}_{\mathrm{c}} \mathrm{dm}^{-3}$; CEC (Cation Exchange Capacity) $=48$ and $41 \mathrm{mmol}$ $\mathrm{dm}^{-3} ; \mathrm{V}$ (base saturation) $=39$ and $29 \% ; \mathrm{S}$ (Sulfur) $=8$ and $16 \mathrm{mg} \mathrm{dm}^{-3} ; \mathrm{B}$ (Boron) $=0.18$ and $0.16 \mathrm{mg} \mathrm{dm}^{-3}$; 
$\mathrm{Cu}$ (Copper) = 0.94 and $1.22 \mathrm{mg} \mathrm{dm}^{-3} ; \mathrm{Fe}$ (Iron) = 60 and $249 \mathrm{mg} \mathrm{dm}^{-3} ; \mathrm{Mn}$ (Manganese) = 3.44 and $4.06 \mathrm{mg} \mathrm{dm}^{-3} ; \mathrm{Zn}(\mathrm{Zinc})=1.12$ and $1.32 \mathrm{mg} \mathrm{dm}^{-3}$.

For particle size analysis, the results for $0-20 \mathrm{~cm}$ and $20-40 \mathrm{~cm}$ were: Clay $=269$ and $305 \mathrm{~g} \mathrm{~kg}^{-1}$; silt $=76$ and $175 \mathrm{~g} \mathrm{~kg}^{-1}$; sand $=555$ and $520 \mathrm{~g} \mathrm{~kg}^{-1}$; coarse sand $=158$ and $153 \mathrm{~g} \mathrm{~kg}^{-1}$; fine sand $=397$ and $368 \mathrm{~g} \mathrm{~kg}^{-1}$, classified as medium texture.

Limestone was applied according to the methods in Comissão de fertilidade do solo do Estado de Minas Gerais - CFSEMG (1999). Limestone was applied at a dose of $1.2 \mathrm{t} \mathrm{ha}^{-1}$ to raise the base saturation to $60 \%$ and gypsum was applied at a dose of $1.0 \mathrm{t} \mathrm{ha}^{-1}$ to improve the environment at the root layer $(20-40 \mathrm{~cm})$. Limestone and gypsum applications were conducted in June 2013 and incorporated into the soil at $20 \mathrm{~cm}$ with a disc harrow.

The soil was tilled using a harrow in two phases, the first in June for lime incorporation and the second in December, prior to sowing and the two operations with disc harrows. Between the first and second harrowing, zinc and boron were sprayed, from the sources of zinc sulfate $\left(18 \mathrm{~kg} \mathrm{ha}^{-1}\right)$ and boric acid $\left(6 \mathrm{~kg} \mathrm{ha}^{-1}\right)$ respectively, with a spray volume of $400 \mathrm{~L} \mathrm{ha}^{-1}$.

After tillage, the first sowing occurred (corn hybrid AG 8061) on December 21, 2013. In the same area, the second sowing (corn hybrid AG 5055) occurred on January 7, 2015, in a no-tillage system. In both years, there were 60,000 plants per hectare, with row spacing of $0.50 \mathrm{~m}$.

The plants were established in 6 rows of $10 \times 3 \mathrm{~m}$ plots, with four replications. The experimental design was stripes with split plots. Three phosphate fertilizer application methods (single furrow, double furrow, and broadcast) were used in the plots. The sub plots were used for the five doses $(0.0$, $50.0,100.0,200.0$, and $400.0 \mathrm{~kg} \mathrm{ha}^{-1}$ of $\mathrm{P}_{2} \mathrm{O}_{5}$ ) corresponding respectively to zero, half, one, two, and four times the dose indicated by CFSMG (1999) for corn cultivation in the state of Minas Gerais. The broadcast-spread phosphate fertilizer was incorporated into the soil in a $0-10 \mathrm{~cm}$ layer, with a disc harrow. The plots that received broadcast phosphate fertilizer were not fertilized in the second planting. At harvest, $2 \mathrm{~m}$ from each end of the plot and one row on each side of the plot were disregarded, leaving a harvesting ground area of $12 \mathrm{~m}^{2}$.

Granulated monoammonium phosphate (MAP) $\left(\mathrm{N}=10 \%\right.$ and $\left.\mathrm{P}_{2} \mathrm{O}_{5}=52 \%\right)$ was used as a $\mathrm{P}$ source during sowing. Potassium chloride $\left(\mathrm{K}_{2} \mathrm{O}=58 \%\right)$ was broadcast applied in a dose of $140 \mathrm{~kg} \mathrm{ha}^{-1}$ when the corn plants were at V3 phenological stage (three fully expanded leaves). Also at the V3 stage, N, as ammonium nitrate $(\mathrm{N}=32 \%)$, was broadcast applied at the amount necessary to reach $140 \mathrm{~kg} \mathrm{ha}^{-1}$ of $\mathrm{N}$ (sowing plus $\mathrm{N}$ coverage fertilization).

In the V6 stage (six fully expanded leaves), the herbicide mesotrione $\left(480 \mathrm{~g} \mathrm{~L}^{-1}\right)+$ atrazine $\left(500 \mathrm{~g} \mathrm{~L}^{-1}\right)$ was applied in a tank mixture of $86 \mathrm{~mL} \mathrm{ha}^{-1}$ active constituent (a.c) and $1.25 \mathrm{~L} \mathrm{ha}^{-1}$ a.c, respectively, with a spray volume of $300 \mathrm{~L} \mathrm{ha}^{-1}$.

When the female inflorescence of the corn plant appeared, the middle third of the first leaf located below and at the opposite side of the ear was collected to evaluate the P content, as indicated by Malavolta, Vitti, and Oliveira (1997). Twenty leaves per sub plot were sampled.

The harvest proceeded when the grains reached $18 \%$ humidity, and the sub plot weight was subsequently adjusted to $13 \%$ humidity to calculate the yield.

At harvest, four plants were harvested from each sub plot. These plants were then crushed and dried in an oven at temperatures ranging from $65^{\circ} \mathrm{C}$, until they reached a constant weight. The $\mathrm{P}$ content was determined in the grains and in the shoot of the plant (stem + leaves + ear), according to the method previously mentioned for leaf analysis. This method is based on the mass of the dry matter and measures the accumulation of the nutrient in the shoot of the plants.

To evaluate the cumulative yield for the two seasons, the yield of both years was added. The doses of phosphate fertilizers used each year in sowing were also added to obtain a cumulative dose. After each harvest, 16 new soil samples were collected per sub plot at $0-20 \mathrm{~cm}$ to evaluate the residual $\mathrm{P}$ content in each planting row.

To statistically evaluate the effects of the different $\mathrm{P}$ application methods, analyses of variance were performed and the averages were compared by the Tukey's test $(p=0.05)$. A polynomial regression analysis was used for the doses, opting for a significant model provided by the $F$-test 
( $p=0.01$ or 0.05 ) with a higher determination coefficient. The Agroestat software (Barbosa and Maldonado Junior, 2015) was used for all statistical analyses.

\section{Results and discussion}

The water requirement of maize varies from 450 to $600 \mathrm{~mm}$ per productive cycle (from germination to physiological maturity), varying the need according to the phenological stage of the crop, and the packaging is the phase of higher demand (Embrapa, 2010). Under the design conditions, it is observed that the rainfall and temperature indices were within what is considered normal for the crop (Figure 1 and Figure 2)

During both agricultural seasons, the soil content of $\mathrm{P}$ varied according to the different doses and $\mathrm{P}_{2} \mathrm{O}_{5}$ application methods (Figure $3 \mathrm{a}$ and $3 \mathrm{~b}$ ). In the first year, $\mathrm{P}_{2} \mathrm{O}_{5}$ application increased the nutrient content in the soil, reaching a maximum of 21 and $28 \mathrm{mg} \mathrm{dm}^{-3}$ at doses of 218 and $400 \mathrm{~kg}$ $\mathrm{ha}^{-1}$ applied in single furrow and broadcast, respectively. No change in the $\mathrm{P}$ content in the soil was observed for the double furrow applications (Figure 3a). At a dose of $50 \mathrm{~kg} \mathrm{ha}^{-1} \mathrm{P}_{2} \mathrm{O}_{5}$, the residual effect was greater for single furrow than for broadcast application, while at a dose of $100 \mathrm{~kg} \mathrm{ha}^{-1}$ $\mathrm{P}_{2} \mathrm{O}_{5}$ there was no difference between the methods. At $200 \mathrm{~kg} \mathrm{ha}^{-1} \mathrm{P}_{2} \mathrm{O}_{5}$, single furrow and broadcast did not differ between each other but were more than double furrow. However, at a dose of $400 \mathrm{~kg} \mathrm{ha}^{-1} \mathrm{P}_{2} \mathrm{O}_{5}$, the broadcast application led to greater soil $\mathrm{P}$ content than did the other tested methods of fertilizer application.

Wheater data 2014

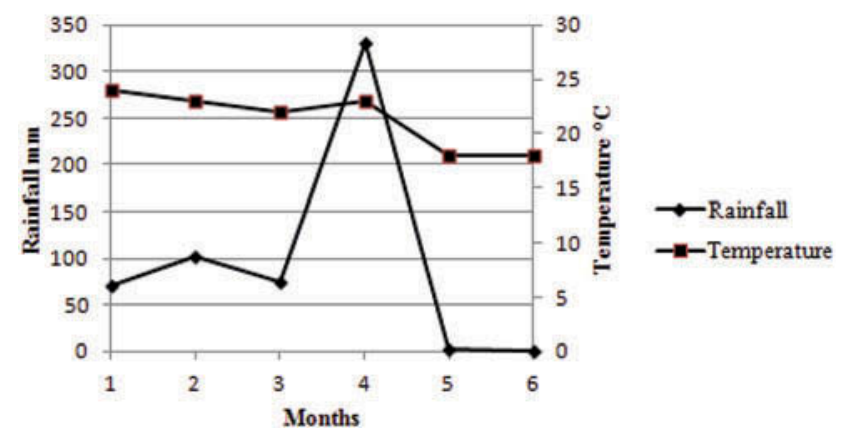

Figure 1. Wheater data -first year (2014).

\section{Wheater data 2015}

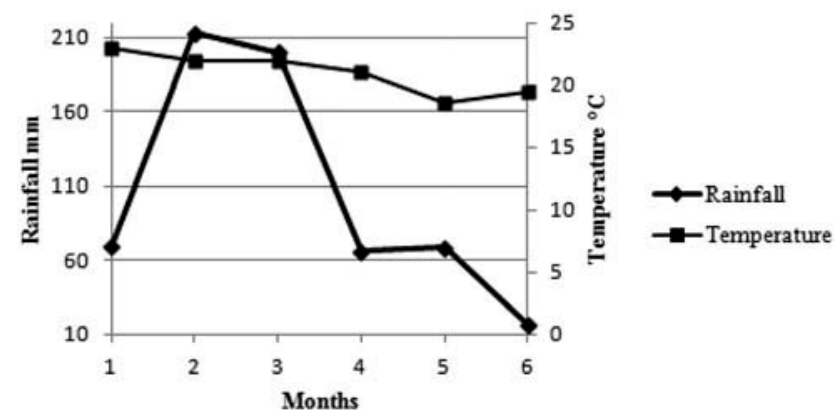

Figure 2. Weather conditions- second year (2015). 
(a)

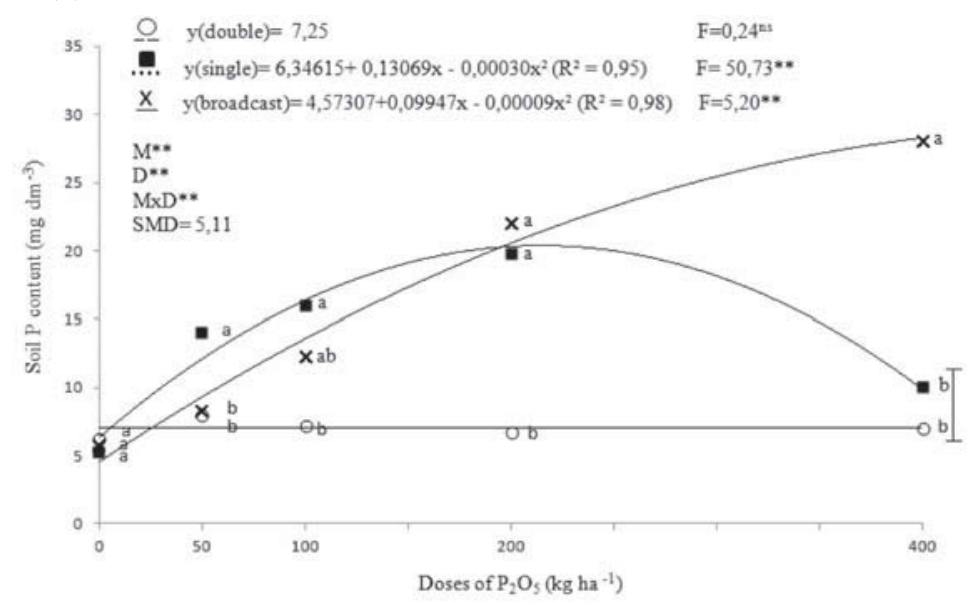

(b)

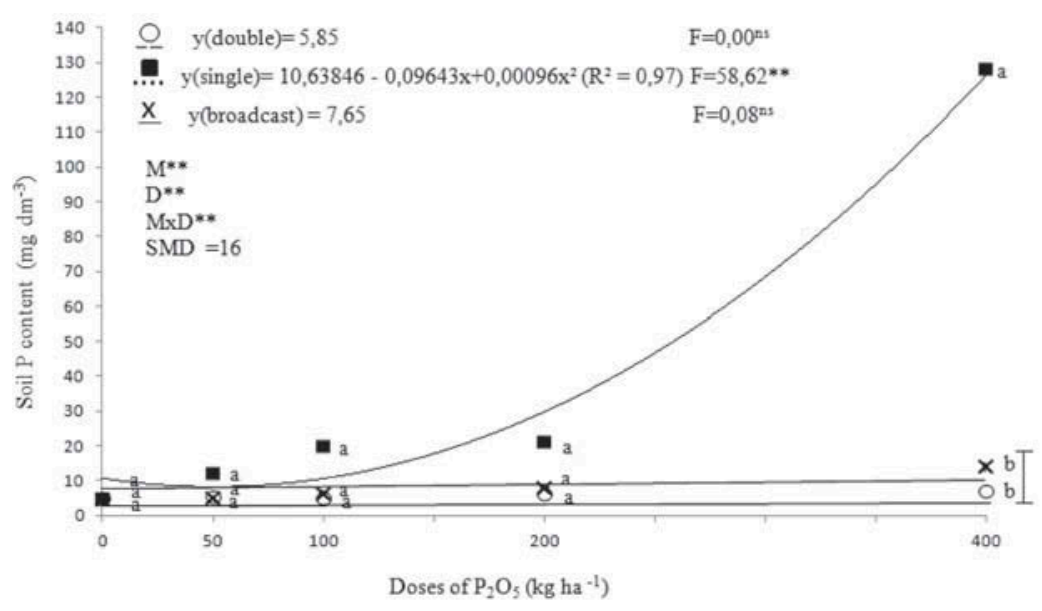

Figure 3. Effects of phosphorus $(P)$ doses for different application methods (single furrow, double furrow, and broadcast) on the $P$ content in the soil cultivated with corn crop on the (a) first and (b) second years of cultivation. ${ }^{* *}$, : Significant at 1 and $5 \%$ levels of probability by the $F$-test; ${ }^{\text {ns. }}$ not significant by the $F$-test.

In the second year, only the single furrow application led to an increased nutrient content in the soil, reaching a maximum value of $128 \mathrm{mg} \mathrm{dm}^{-3}$ when the higher dose of $\mathrm{P}$ was applied (Figure $3 \mathrm{~b}$ ). The $\mathrm{P}$ fertilization from the applied doses led to a soil content that was classified as high $\left(>20 \mathrm{mg} \mathrm{dm}^{-3}\right)$, as indicated by CFSEMG (1999) in medium textured soils. The effects of these application methods on nutrient content in the soil are related to the soil sampling method. The double furrow method in both years presented lower levels of $P$ in the soil because the uptake was done between the double furrows. The plants from sub plots that received lower doses of $\mathrm{P}$ showed female flowering 7 to 10 days later than did the other sub plots, as was also observed by Fidelis, Miranda, and Erasmus (2009), who verified the same change in a crop cycle, under P deficiency.

The P levels increased the leaf nutrient content regardless of the application method (Figure 4). The doses of $\mathrm{P}$ increased the leaf content of the nutrient with a quadratic fit for the broadcast application, reaching a maximum dose of $284 \mathrm{~kg} \mathrm{ha}^{-1} \mathrm{P}_{2} \mathrm{O}_{5}$ associated with a leaf content of $2.6 \mathrm{~g} \mathrm{~kg}^{-1}$. However, the single and double furrow methods promoted an increase in leaf $\mathrm{P}$ with a linear fit, reaching a maximum of 2.52 and $2.54 \mathrm{~g} \mathrm{~kg}^{-1}$, respectively, at a dose of $400 \mathrm{~kg} \mathrm{ha}^{-1} \mathrm{P}_{2} \mathrm{O}_{5}$ (Figure 4). The above values indicate that the leaf $\mathrm{P}$ 


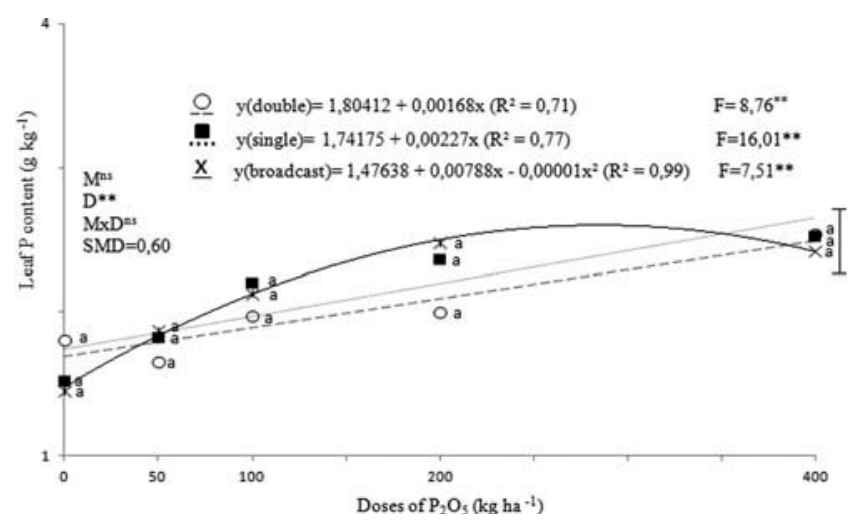

Figure 4. Effects of phosphorus doses for different application methods (single furrow, double furrow, and broadcast) on the leaf $P$ content of the second year corn crop. ${ }^{* *}$, $:$ : Significant at 1 and $5 \%$ level of probability by the $F$-test; ${ }^{\text {ns }}$ : not significant by the F-test.

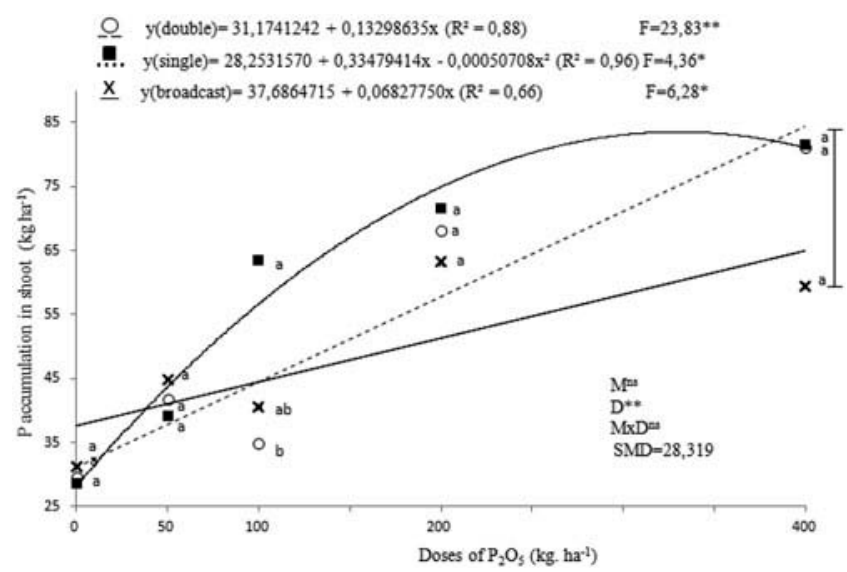

Figure 5. Effects of phosphorus $(P)$ doses for different application methods (single furrow, double furrow, and broadcast) on $P$ accumulation in the shoot of the second year corn crop $^{* *}$. ${ }^{*}$ : Significant at 1 and $5 \%$ level of probability by the $F$-test; ${ }^{\text {ns }}$ : not significant by the $F$-test.

content of corn plants is within the sufficiency standards, which is 2.5 to $3.5 \mathrm{~g} \mathrm{~kg}^{-1}$, as reported by Malavolta, Vitti, and Oliveira (1997). The $\mathrm{P}$ applications increased the accumulation of $\mathrm{P}$ in the dry matter of the shoot regardless of the application mode. The greatest accumulation of $\mathrm{P}\left(83 \mathrm{~kg} \mathrm{ha}^{-1}\right)$ occurred at a dose of $330 \mathrm{~kg}$ $\mathrm{ha}^{-1} \mathrm{P}_{2} \mathrm{O}_{5}$, for the single furrow application (Figure 5). At a dose of $100 \mathrm{~kg} \mathrm{ha}^{-1} \mathrm{P}_{2} \mathrm{O}_{5}$, the single furrow application led to the highest $\mathrm{P}$ accumulation. At a dose of $400 \mathrm{~kg} \mathrm{ha}^{-1} \mathrm{P}_{2} \mathrm{O}_{5}$, single and double furrow had higher $\mathrm{P}$ accumulations than did the broadcast application. The analysis of the flag leaf indicated a linear increase in the absorption of $\mathrm{P}$ with increasing rates of the $\mathrm{P}$ fertilizer, with accumulation of $1.6 \mathrm{mg} \mathrm{P}$ in the leaves per $\mathrm{kg}$ of $\mathrm{P}_{2} \mathrm{O}_{5}$ added to the soil. Despite the increasing absorption with higher $\mathrm{P}$ rates, the $\mathrm{P}$ content in the leaves at the rate $0 \mathrm{~kg} \mathrm{ha}^{-1}$ of $\mathrm{P}_{2} \mathrm{O}_{5}$ was $88 \%$ of the content achieved with the highest rate $\left(160 \mathrm{~kg} \mathrm{ha}^{-1}\right.$ the $\mathrm{P}_{2} \mathrm{O}_{5}$ ) (Sa, Briedis, and Ferreira, 2013).

In the first harvest, the doses of $\mathrm{P}$ applied to the soil interfered with the $\mathrm{P}$ content of corn grain depending on the nutrient application method (Figure 6a). This did not occur in the second harvest when the application methods did not interfere with the grain $\mathrm{P}$ content (Figure 6b). The residual $\mathrm{P}$ in the soil, left from the first crop season, may have contributed to the absence of interference of the $P$ application methods in the grain P content in the second crop season. For the single furrow and 
(a)

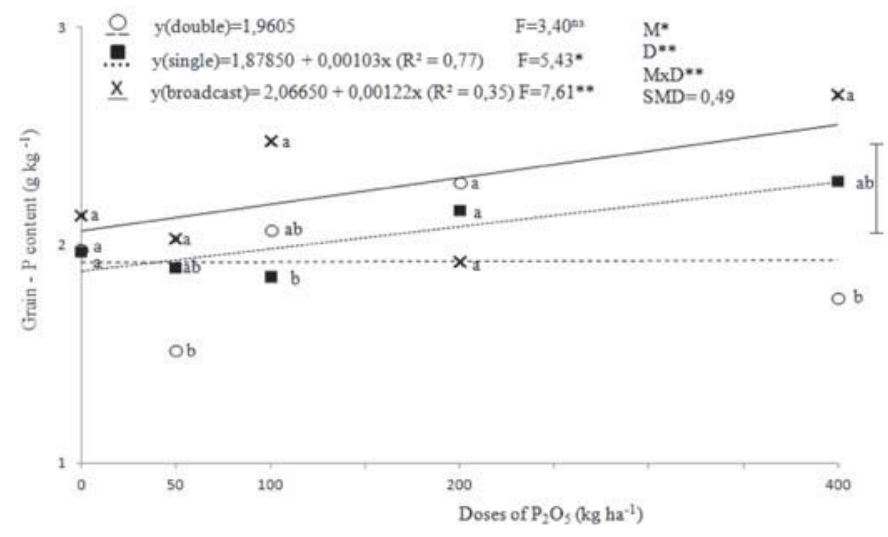

(b)

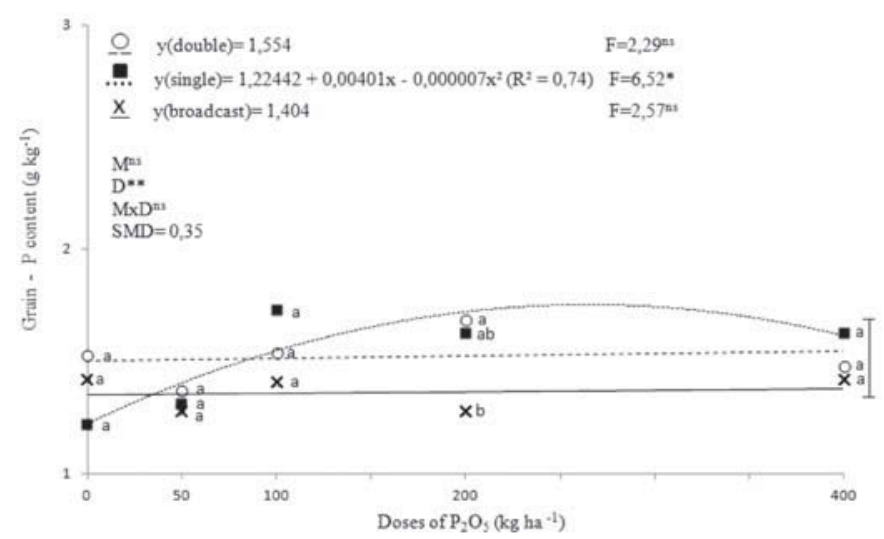

Figure 6. Effects of phosphorus $(P)$ doses for different application methods (single furrow, double furrow, and broadcast) in the grain $P$ content in the (a) first and (b) second year corn crop. ${ }^{* *},{ }^{*}:$ Significant at 1 and $5 \%$ level of probability by the $F$-test; ${ }^{\text {ns}}$ : not significant by the F-test.

broadcast methods, the grain $\mathrm{P}$ content showed a linear relationship to the applied doses. For double furrow, the dose did not have a significant effect. The first year doses of 400, 200, and $100 \mathrm{~kg} \mathrm{ha}^{-1} \mathrm{P}_{2} \mathrm{O}_{5}$ promoted a higher grain $\mathrm{P}$ content, reaching 2.30, 2.13, and $2.12 \mathrm{~g} \mathrm{~kg}^{-1}$ respectively, differing from the dose of $50 \mathrm{~kg} \mathrm{ha}^{-1} \mathrm{P}_{2} \mathrm{O}_{5}$, which promoted a grain content $1.81 \mathrm{~g} \mathrm{~kg}^{-1}$. For the second harvest, there was no significant interaction between the method of $\mathrm{P}$ application and the dose. There was an increase with a quadratic adjustment in the $\mathrm{P}$ content in the grain depending on the dose applied. The broadcast and single furrow applications of phosphate fertilizer promoted higher grain $\mathrm{P}$ contents than did the double furrow application. In the second year, the same pattern of dose responses was maintained, and the $\mathrm{P}$ contents in the grain were lower than those in the first year $(1.60,1.56,1.53$, and $1.32 \mathrm{~g} \mathrm{~kg}^{-1}$ at doses of 400, 200, 100, and $50 \mathrm{~kg} \mathrm{ha}^{-1} \mathrm{P}_{2} \mathrm{O}_{5}$, respectively).

Using the grain $\mathrm{P}$ content and yield in the first year of cultivation, one can estimate that the total $\mathrm{P}$ exported by the grains would be $2.27,2.05$, and $1.95 \mathrm{~kg} \mathrm{t}^{-1}$ for the broadcast, single furrow, and double furrow application methods, respectively. These values are lower than those mentioned by Coelho (2006), who observed $4.19 \mathrm{~kg} \mathrm{t}^{-1}$ for a grain yield of $7.9 \mathrm{t} \mathrm{ha}^{-1}$. The doses of $\mathrm{P}$ applied to the soil affected corn crop yield depending on the application method for the two seasons individually (Figure $7 \mathrm{a}, \mathrm{b}$ ), and also cumulatively (Figure $7 \mathrm{c}$ ). The $\mathrm{P}$ doses applied by broadcasting stood out from localized applications in the first harvest, reaching a maximum yield of $379 \mathrm{~kg} \mathrm{ha}{ }^{-1} \mathrm{P}_{2} \mathrm{O}_{5}$ 


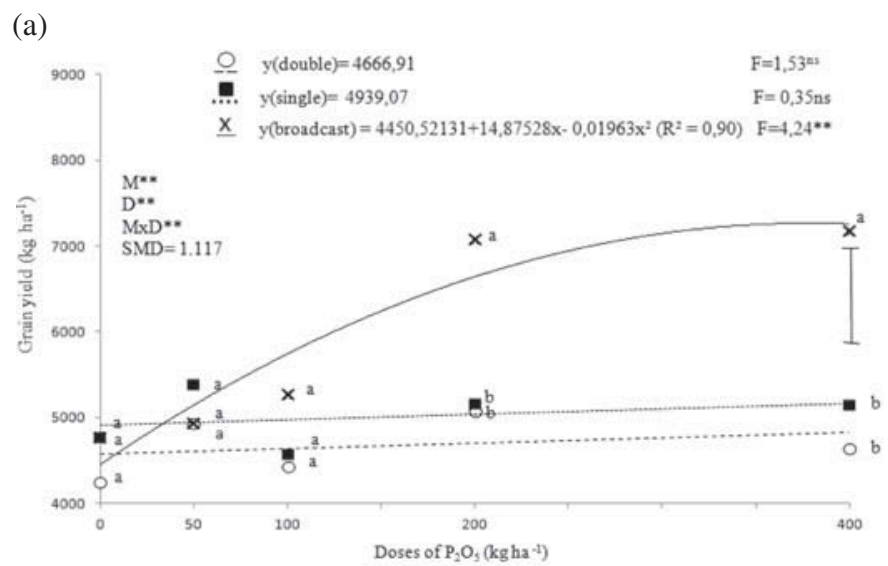

(b)
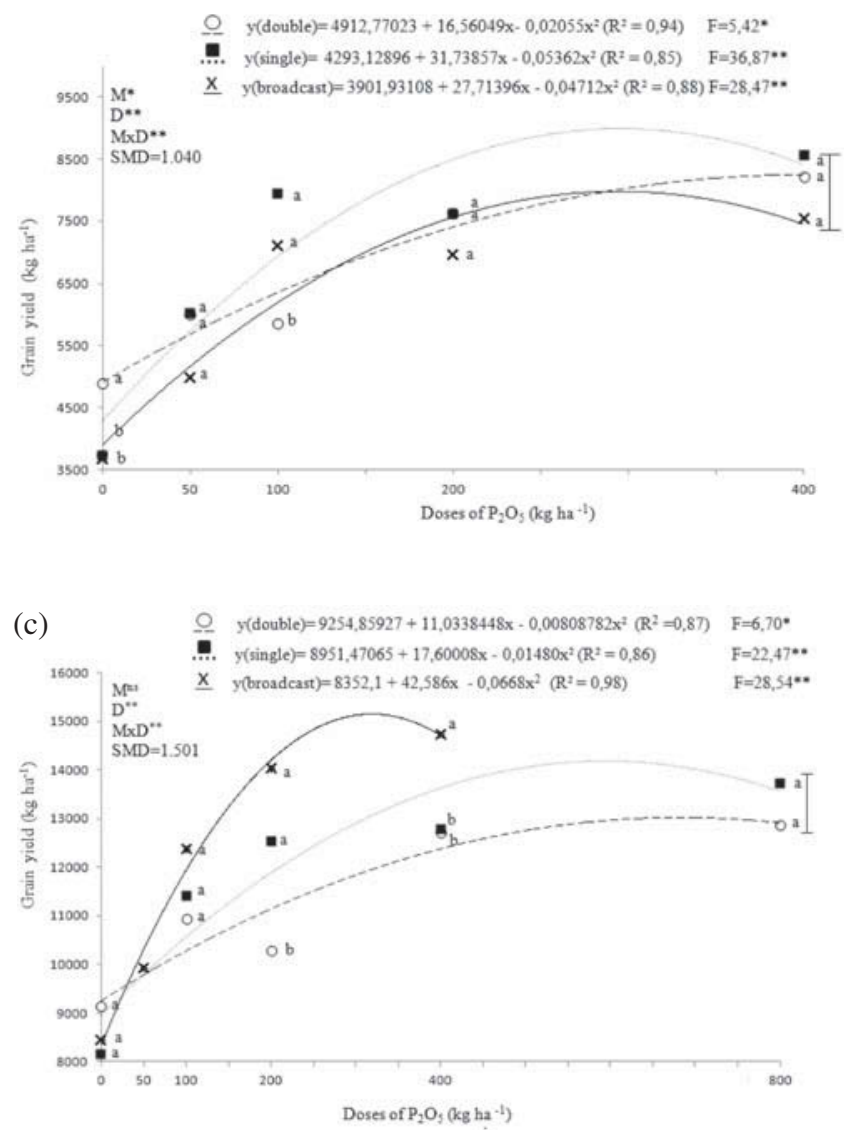

Figure 7. Effects of phosphorus (P) doses for different application methods (single furrow, double furrow, and broadcast) on corn crop yield in the (a) first, (b) second year, (c) accumulated yield two seasons. ${ }^{* *}$, : : Significant at 1 and $5 \%$ level of probability by the F test; ${ }^{\text {ns }}$ : not significant by the $F$-test.

(Figure 7a). However, the single furrow and broadcast applications provided the highest yields during the second harvest, occurring at a dose of $100 \mathrm{~kg} \mathrm{ha}^{-1}$ of $\mathrm{P}_{2} \mathrm{O}_{5}$ (Figure $7 \mathrm{~b}$ ). 
The topdress application was the most responsive, providing a yield of $10,717 \mathrm{~kg} \mathrm{ha}^{-1}$ in comparison with $9,240 \mathrm{~kg} \mathrm{ha}^{-1}$ obtained by the application in the furrow. The control treatment gave the lowest yield (7,542 $\mathrm{kg} \mathrm{ha}^{-1}$ ) (Sá, Briedis, and Ferreira 2013).

The $\mathrm{P}$ doses for double furrow, single furrow, and broadcast methods that provided maximum yields of $8,248,8,989$, and $7,975 \mathrm{~kg} \mathrm{ha}^{-1}$ in the second harvest were 400, 296, and $294 \mathrm{~kg} \mathrm{ha}^{-1} \mathrm{P}_{2} \mathrm{O}_{5}$, respectively (Figure $7 \mathrm{~b}$ ).

For the two-year cumulative productivity, the single furrow and broadcasting application methods provided the highest productivity at a dose of $400 \mathrm{~kg} \mathrm{ha}^{-1} \mathrm{P}_{2} \mathrm{O}_{5}$ (Figure $5 \mathrm{c}$ ). In addition, the $\mathrm{P}$ doses that provided maximum cumulative productivities of $13,000,14,180$, and $15,139 \mathrm{~kg} \mathrm{ha}^{-1}$ were 682, 594, and $319 \mathrm{~kg} \mathrm{ha}^{-1} \mathrm{P}_{2} \mathrm{O}_{5}$ for double furrow, single furrow, and broadcast applications, respectively (Figure $7 \mathrm{c}$ ). The $\mathrm{P}$ doses for broadcast application are close to those reported by Orioli Júnior et al. (2008), who looked at three consecutive harvests and found that a dose of $270 \mathrm{~kg} \mathrm{ha}{ }^{-1} \mathrm{P}_{2} \mathrm{O}_{5}$ broadcast spread is beneficial for corn crops.

The accumulated production in both harvests for doses of $200 \mathrm{~kg} \mathrm{ha}^{-1} \mathrm{P}_{2} \mathrm{O}_{5}$ indicated that the broadcast and single furrow applications resulted in increased yields. Moreover, a higher dose of $\mathrm{P}_{2} \mathrm{O}_{5}$ $\left(400 \mathrm{~kg} \mathrm{ha}^{-1}\right.$ ) stood out in the broadcast application (Figure $7 \mathrm{c}$ ), maybe due to a larger fertilized soil volume, that would increases the contact of the roots with phosphate fertilizer. These results differ from those found by Prado, Fernandes, and Roque (2001) who found higher yields from using double furrow than from using broadcast application on a corn crop grown on oxisol. Prado, Fernandes, and Roque (2001) suggested that the broadcast application might have favored a greater adsorption of the element in the soil, thereby damaging crop production. In addition, wider plant row spacing $(0.90 \mathrm{~m})$ was used, which could inhibit a uniform distribution of the root system and undermine the efficiency of broadcast fertilization. However, in this study, the reduced spacing $(0.50 \mathrm{~m})$ may have provided better root distribution, which may have favored higher $\mathrm{P}$ absorption. The higher absorption with the broadcast application may be associated with the medium texture oxisol, which has less $\mathrm{P}$ adsorption, especially in soils with lower ferric oxide, since its element content $\left(<360 \mathrm{~g} \mathrm{~kg}^{-1}\right.$ of $\left.\mathrm{Fe}_{2} \mathrm{O}_{3}\right)$ is lower than that in other oxisols ( $>360 \mathrm{~g} \mathrm{~kg}^{-1}$ of $\mathrm{Fe}_{2} \mathrm{O}_{3}$ ) (Embrapa 2006).

Novais et al. (1985) indicated that when $\mathrm{P}$ is evenly distributed in tropical soils, it induces the development of conditions for high crop yields. Similar results were reported by Barreto and Fernandes (2002) who found that broadcast fertilization resulted in a higher P uptake by corn plants than did furrow fertilization. This is because a uniform root distribution system provides the best condition for the roots to absorb water and nutrients, thus resulting in increased grain yield.

Broadcast application may also be more effective than furrow application because, as shown by this research, only one $\mathrm{P}$ fertilizer application during the first year, at the highest dose, was enough to provide high productivity for two seasons. This would avoid an annual re-application, thereby reducing costs and optimizing sowing time by not having to include the macronutrient in the seeder.

\section{Conclusion}

Of the three methods tested, the broadcast application method of $\mathrm{P}$ fertilizer in the first year at a dose of $319 \mathrm{~kg} \mathrm{ha}^{-1}$ of $\mathrm{P}_{2} \mathrm{O}_{5}$ provided the highest accumulated yield over two seasons. This is therefore a viable method for growing corn using reduced row spacing and on medium textured oxisol.

In the second crop season, the $\mathrm{P}$ application methods did not influence the $\mathrm{P}$ accumulation in the grain or in the plant, neither the $\mathrm{P}$ content in the grain nor in the plant.

\section{References}

Barbosa, J. C., and W. Maldonado Júnior. 2015. Agronomic experimentation \& AgroEstat -System testing statistical analyses agronomic, p. 396. Jaboticabal, Brazil: Gráfica Multipress Ltd.

Barreto, A. C., and M. F. Fernandes. 2002. Produtividade e absorção de fósforo por plantas de milho em função de doses e modos de aplicação de adubo fosfatado em solo de tabuleiro costeiro. Revista Brasileira Ciência Solo 26:151-56. 
Camargo, O. A., A. C. Moniz, J. A. Jorge, and J. M. A. S. Valadares. 2009. Analysis methods chemical, mineralogical and soil physics agronomic institute of campinas. Campinas, Brasil: Instituto Agronômico de Campinas.

Coelho, A. M. 2006. Nutrition and fertilization of corn. Sete Lagoas - Technical Circular Letter 78. Rio de Janeiro, Brazil, Empresa Brasileira de Agropecuária.

Costa, S. E. V. G. de A. 2008. Distribuição de fósforo e de potássio e de raízes e rendimento de milho em sistemas de manejo do solo e da adubação em longo prazo. Porto Alegre UFRS 116 p. Dissertação.

Embrapa. 2013. Sistema Brasileiro de classificação de solos, eds. H. G. dos Santos, P. K. T. Jacomine, L. H. C. dos Anjos, V. A. de Oliveira, J. B. de Oliveira, M. R. Coelho, J. F. Lumbreras, and T. J. F. Cunha. Rio de Janeiro, Brasil: Empresa Brasileira de Agropecuária.

Embrapa Milho e Sorgo. 2010. Sistema de Produção, 1ISSN1679-012X. Versão Eletrônica, 6a edição.

Embrapa. 2006. Brazilian system of soil classification. H. G. Dos Santos, P. K. T. Jacomine, L. H. C. Dos Anjos, V. A. De Oliveira, J. B. De Oliveira, M. R. Coelho, J. F. Lumbreras, and T. J. F. Cunha. eds, Rio de Janeiro, Brazil: Empresa Brasileira de Agropecuária.

Embrapa Milho e Sorgo, Production system 2011 1ISSN 1679-012X Eletronic Version. 2011. 7th ed. Sete Lagoas, Brazil: Embrapa.

Fidelis, R. R., G. V. Miranda., and E. A. L. Erasmo. 2009. Selection of corn populations at high and low dose of phosphorus in cerrado soil. Pesquisa Agropecuária Tropical 39:285-93.

Köppen, W., and R. Geiger. 1928. Klimate der Erde. Gotha: Verlag Justus Perthes. Wall-map $150 \mathrm{~cm} \times 200 \mathrm{~cm}$

Malavolta, E., G. C. Vitti, and A. De Oliveira. 1997. Evaluation of the nutritional status of plants, 2nd ed. Brazil: Piracicaba- Potafós.

Marchão, R. L., E. M. Brasil, J. B. Duarte, C. M. Guimarães, and J. A. Gomes. 2005. Plant density and agronomic characteristics of corn hybrids under reduced spacing. Pesquisa Agropecuária Tropical 35:93-101.

Nascimento, E. S., E. G. Gilo, F. E. Torres, C. A. Da Silva Junior, L. V. A. Oliveira, and E. A. D. S. Laurenção. 2012. Resposta de hibrido de milho a diferentes espaçamentos entre linhas. Nucleus 9:131-39.

Novais, R. F. D., R. P. Ferreira, J. C. L. Neves, and N. F. De Barros. 1985. Phosphorus absorption and corn growth with root system partially exposed to phosphorus source. Pesquisa Agropecuária Brasileira 20:749-54.

Novais, R. F. D., and T. J. Smyth. 1999. Phosphorus in soil and plants in tropical conditions Viçosa. Brasil: Universidade Federal de Viçosa.

Orioli Júnior, V., E. L. M. Coutinho, A. A. Otsubo, and A. M. Coutinho Neto. 2008. Corrective phosphate fertilizer for corn. Nucleus 5:1982-2278.

Paludo, A. L. 2015. Adubação a Lanço Versus na Linha Disponível http://www.pioneersementes.com.br/

Prado, R. M., M. F. Fernandes, and C. G. Roque. 2001. Corn crop response the application modes and phosphorus doses maintenance fertilization. Revista Brasileira Ciência Do Solo Do Solo 25:83-90.

Raij, B. V., J. C. Andrade, H. Cantarella, and J. A. Quaggio. 2001. Chemical analysis to evaluate the fertility of tropical soils. Campinas: Instituto Agronômico de Campinas.

Ribeiro, A. C., P. T. G. Guimarães, and V. H. Alvarez, eds. 1999. Comissão de fertilidade do solo do estado de Minas Gerais CFSEMG . Recommendations for the Use of Lime and Fertilizer in Minas Gerais 5th Approach 25-32:314-15.

Sá, J. C. D. M., C. Briedis, and A. D. O. Ferreira. 2013. Desempenho da cultura do milho no plantio direto em resposta ao fósforo e ao modo de fertilização. Revista Ceres, Viçosa 60(1):96-101.Disponível a partir http://www.scielo.br/ scielo.php. Acesso em 04 de novembro de 2016. 10.1590/S0034-737X2013000100014

Sousa, D. M. G., and E. Lobato. 2004. Adubação fosfatada em solos da região do Cerrado. In Fósforo na Agricultura Brasileira. eds. T. Yamada and S. R. S. ABDALLA, 157-200. Piracicaba, SP: Associação Brasileira para Pesquisa da Potassa e do Fosfato.

Sousa, D. G. M., E. Lobato, and T. A. Rein. 2004. Adubação com fósforo. In Cerrado: Correção do solo e adubação, 2nd ed, 147-168. Brasília: Embrapa Informação Tecnológica.

Stryker, R. B., J. W. Gilliam, and W. A. Jackson. 1974. Nonuniform transport of phosphorus from single roots to the leaves of Zea mays. Physiologia Plantarum 30:231-39.

Valadão, F. C. D. A., D. D. Valadão Júnior, O. L. D. S. Weber, and A. I. Weiss 2016. Aspectos da adubação fosfatada em plantio direto. Revista Plantio Direto, ed. 152, março/abril p. 2. 